\title{
Ethnoconstructivism E-Module to Improve Perception, Interest, And Motivation of Students in Class V Elementary School
}

\author{
Asriall $^{1}$, Syahrial $^{*}$, Maison ${ }^{3}$, Dwi Agus Kurniawan ${ }^{4}$, Suci Okta Piyana ${ }^{5}$ \\ Education of Teaching Elementary School, Universitas Jambi \\ e-mail: asrial@unja.ac.id, syahrial.karea@gmail.com,maison@unja.ac.id, dwiagus.k@unja.ac.id, \\ suci.okta.piyana@gmail.com
}

\begin{abstract}
This study aims to develop learning media in electronic form using the 3D Pageflip application for fifth grade elementary school students and look at students' perceptions, interests, and motivations in the use of ethnoconstructivism e-modules in learning. The method in this study was adopted from Branch with the stages of analysis, design, development, implementation, and evaluation. Where, the subjects in this study amounted to 30 students who came from grade school students. In this study descriptive statistics are used in the form of mean, median, mode, min, max, and category to see students' perceptions, motivations, and interests in the ethnoconstructivism e-module. Based on the results of the assessment in this study, students' perception was $73.4 \%$ (enough). Student interest is $80.1 \%$ (good). And student motivation is $93.4 \%$ (good). The data generated shows that the electronicbased ethnocontructivism module is able to support students in learning, it can be viewed from the affective aspects of these students.
\end{abstract}

Keywords : Learning, ICT, learning media, electronic modules, 3D Pageflip Professional

\section{Introduction}

Education plays an important role in advancing a country because it can improve the quality of human resources. In line with (Djidu \& Jailani, 2018) Good and quality education are a benchmark for the quality of human resources. Improving the quality of human resources in education can be done by facilitating student learning activities. According to (Astalini, Kurniawan, \& Sumaryanti, 2018; Kurniawan, Astalini \& Anggraini, 2019) "Education is basically a conscious effort to foster the potential of human resources especially students which are carried out by guiding and facilitating student learning activities". If the quality of human resources is still not good, an increase in education is needed. One of them is marked by education that has been able to shape the character of each individual for the better. In accordance with the function of national education listed in Law number 20 of 2003 Article 3 on the National Education System, namely education functions to develop capabilities and shape the character and civilization of a dignified nation in order to educate the life of the nation (Sukasni \& Efendy, 2017; Budiarti, Harlis, \& Natalia, 2020). Quality education cannot be separated from a teacher who is able to utilize technology in the learning process. Because with the advances in technology can make it easier for teachers and students to access learning and learning resources that use ICT will get better results. Learning resources are all things that can be used to facilitate learning to achieve learning goals and improve student performance in learning and learning (Asrial et al., 2019; Astalini et al, 2019). As technology advances, teachers are also required to be able to improve their competencies in the learning process so that learning objectives can be achieved well. In line with Cahyanti, Sinaga, \& Amsor, (2018) said the effort that must be done by teachers in improving their competence is to design a variety of learning styles, media and learning resources that are in accordance with student learning needs.

The teacher has a very important role in learning activities. Therefore, teachers must design learning activities as well as possible in order to be meaningful. Learning is an activity that is designed by the teacher as well as possible so that the learning process or activities

\footnotetext{
Corresponding author.

Received 4 August 2019; Accepted 14 March 2020; Available online 31 March 2020 (c) 2020 JPI. All Rights Reserved
} 
occur in students. As a teacher must be able to manage learning well, where students easily understand a concept being learned. In line with Asrial et al (2019) and Darmaji et al (2019), said learning that connects real situations, where the teacher connects learning with the environment around participants will cause learning to be more meaningful, because with direct experience students will easily understand the concepts being learned and relate them to concepts that are already understood. The teacher plays an important role in the learning process, because the teacher has a very large role in the class such as enriching the knowledge of students (Abdel Rahman, 2016).

The learning process will run well, if the teacher uses technology as a learning medium. Utilization of technology as a learning medium will facilitate teachers in delivering the material (Perdana et al, 2017). With the media support the learning process, this will facilitate both educators and students in carrying out learning and have a positive impact on students in the implementation of learning, learning media is needed to facilitate teachers. Learning media can be in the form of pictures, textbooks, e-modules and other technological tools. Teachers who use technology as a learning medium can make the learning process more interesting and seem more real, so students do not feel bored with what is being learned. In line with Darmaji et al (2019) instructional media can demonstrate certain facts, concepts, principles or procedures to make them appear more concrete. So that with the media can provide a more tangible experience, motivating, increasing absorption and memory of students in learning.

The increasingly sophisticated technological advances in education can be utilized by teachers to develop learning media in electronic form. Computers, audio-visual learning media, are considered to have the advantages of learning rather than using print media (visual), (Darmaji et al, 2019). One of the teaching materials in electronic form is e-module. The module is one of the learning tools that can facilitate student learning because it contains clear objectives, subject matter, activity sheets and can check student understanding independently (Citrawathi, Adnyana, \& Santiasa, 2016). The use of electronic modules is very helpful for teachers in the learning process. (Wulansari, Kantun, \& Suharso, 2018) e-modules are teaching materials that can help students to learn subject matter independently in their use of electronic media. Because the electronic module can help students to learn individually/independently in the classroom, so the teacher in learning only as a facilitator. In line with (Koderi, 2017) An electronic module was developed to enable students to do and improve learning outcomes independently. The electronic modules used in learning must be designed by the teacher very interestingly, such as the teacher displaying several pictures and videos in the module so that students do not feel bored in the learning process and the objectives of learning can be achieved easily. In line with (Imansari \& Sunaryantiningsih, 2016) electronic modules can display text, images, animations, and videos through computers and the existence of e-modules can improve students' understanding of concepts and learning outcomes (Suyatna et al, 2018).

The use of e-modules as teaching materials that use technology can make it easier for teachers to introduce cultures that exist around students. Where the teacher can associate the material being studied with local wisdom that is around in the lesson. The integration aims to make students aware of the local wisdom in their area so that values can be preserved within that local wisdom. Local wisdom includes a variety of knowledge, views, and values both obtained from previous generations and various experiences in the present (Asrial et al, 2019; Maison et al, 2019). Each region has its own local wisdom gained through community experience. Local wisdom is the intelligence of certain people which is obtained through their experience and not necessarily owned by other communities (Wijana, 2015). Local wisdom needs to be preserved, especially the values contained therein by students so as not to be influenced by outside cultures that can affect one's character. In life, local wisdom is used as a guide because it contains values that have been passed down through generations and are believed to be able to bring good influence in society. In line with Alqomayi (2018) local wisdom is a product of the culture of the past which is worthy of being constantly held on to life. Although local value, but the value contained therein is considered to be very universal. 
Based on the results in the field, teachers have difficulty implementing learning related to ethno in the learning process. Because the teacher cannot use technology as a learning medium. Even though in every school there are already several kinds of technology that support the learning process such as computers and laptops. Therefore, ethnocontructivism electronic module based on 3D Pageflip Professional software is needed to facilitate teachers in delivering learning material related to the culture of students' environments.

The electronic module developed using 3D Pageflip Professional software has a very attractive appearance, because by using the 3D Pageflip software the module has the appearance of a real book. Where the electronic module based on Pageflip Professional 3D can move like flipping a book, can display images, audio, animation and video that makes users (teachers or students) feel interested to use it in the learning process (Syahrial et al, 2019). Therefore, before using 3D Pageflip Professional teachers must design an electronic module display with very interesting so that in the learning process students feel happy, not easily bored or fed up and the learning material delivered by the teacher can be absorbed easily, and the objectives of learning can be achieved (Manasia, 2015; Astalini et al, 2019; Darmaji et al, 2019; Maison et al, 2020).

This research aims to; (1) Producing 3D Pageflip Professional ethnocontructivism electronic modules that meet good eligibility criteria; (2) Knowing the results of the questionnaire perception, interest, and motivation from the use of ethnocontructivism-based electronic modules 3D Pageflip Professional in learning.

\section{Method}

This research is adapts the Branch (2009), is Analysis, Design, Development, Implementation, Evaluation. For this reason, this study aims to develop learning products that will be used in schools. According to (Silalahi, 2015) development research is research that focuses on product development, both industrial products and learning products in the school world that are systematically tested in the field, evaluated, and refined to meet effective criteria, and quality so that they are suitable for use.

The analysis phase is the first stage before developing a product. At this stage the needs and objectives of learning are analyzed for what students will learn. In line with (Trisiana \& Wartoyo, 2016) The analysis phase is a process of defining what will be learned by the learning participants, namely conducting a needs analysis, identifying problems, and doing a task analysis. After the needs are analyzed, the researcher designs the product to be developed. The design phase consists of compiling electronic module contents such as collecting material, stories, crafts and preparation of instruments equipped with several images, animations and videos to make students interested in learning. In line with (W. Sari, Jufrida, \& Pathoni, 2017) in making e-modules must collect learning material first, then presented with pictures, videos, and animations related to the material. In the development stage, teaching materials in the form of ethnocontructivism electronic module based on 3D Pageflip Professional are made based on the designs that have been designed. In line with Mulyatiningsih (2011) at the development stage, conceptual designs produced at the design stage are realized into products that are ready to be implemented in class. After the development phase, the implementation of 3D Pageflip Professional ethnocontructivism electronic module is implemented in real conditions, namely in the classroom. The 3D Pageflip Professional ethnocontructivism electronic module was tested on grade 5 elementary school students to determine student motivation in learning. In line with (I. P. Sari, 2018) the design or method that has been developed is implemented in a real situation namely in the classroom. The last stage is the evaluation stage, this stage is carried out by conducting a feasibility test on the electronic module ethnocontructivism based on 3D Pageflip Professional and its effect on student learning outcomes. In line with (Tegeh \& Kirna, 2013) an evaluation is carried out to determine the effect of the product on student learning outcomes and broad learning quality.

This research was conducted in State Elementary School 64 / I Muara Bulian, Batanghari in the 2018/2019 school year, with research subjects for all VC grade students totaling 30 students. Data collection techniques used in this study were perception 
questionnaire, questionnaire of interest and student motivation questionnaire on the use of $\mathrm{E}$ Module Ethnocontructivism Based on 3D Pageflip Professional in the learning process. Data obtained from the questionnaire was measured using a Likert scale technique with five answer choices for each statement of the 20 statements for and each answer has its own score interval which can be seen in the following table.

Table 1. The Category of Questionnaire for Perception, Motivation and Interest

\begin{tabular}{cc}
\hline Interval Skor & Category \\
\hline $20.0-36.0$ & Very Not Good \\
$36.1-52.0$ & Not Good \\
$52.1-68.0$ & Enough \\
$68.1-84.0$ & Good \\
$84.1-100$ & Very Good \\
\hline
\end{tabular}

This study uses descriptive qualitative data analysis techniques by describing the results of product development in the form of Mean, Median, Mode, Range, maximum values and minimum values for each variable. To get these results, the data is processed using SPSS 22 software.

\section{Results and Discussion}

This research is a research development that produces teaching materials in the form of ethnocontructivism electronic module based on 3D Pageflip Propessional. The development procedure starts with the needs analysis first. At this stage the needs and objectives of learning are analyzed for what will be learned by students based on the results in the field, especially grade $\mathrm{V}$ elementary school teachers have difficulty in linking learning material with local local wisdom. Therefore the need for teaching materials that the description of the material is related to local culture so that students know the local wisdom in their area and are able to preserve the values contained in local wisdom. The design phase consists of compiling the contents of electronic modules such as materials, stories, crafts and instrument preparation. This stage is carried out by linking materials, stories and crafts with ethno in the local area. At the development stage, the design that has been compiled is made into a product of teaching materials based on ethnoconstructivism using 3D Pageflip. Therefore a 3D Pageflip Professional application is needed to display an ethnocontructivism module.

Electronic module components include the title / cover page, core competencies, basic competencies, learning objectives, ethno stories, questions, material description, evaluation, and crafts.

\subsection{Cover}

The cover contains the module title, class, author name and user.

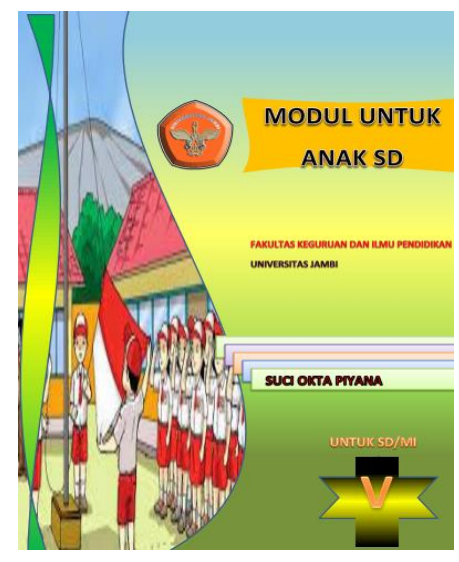

Figure 1. Cover Page 


\subsection{Core Competencies}

This competency consists of spiritual competencies, social competencies, knowledge competencies, and skills competencies.

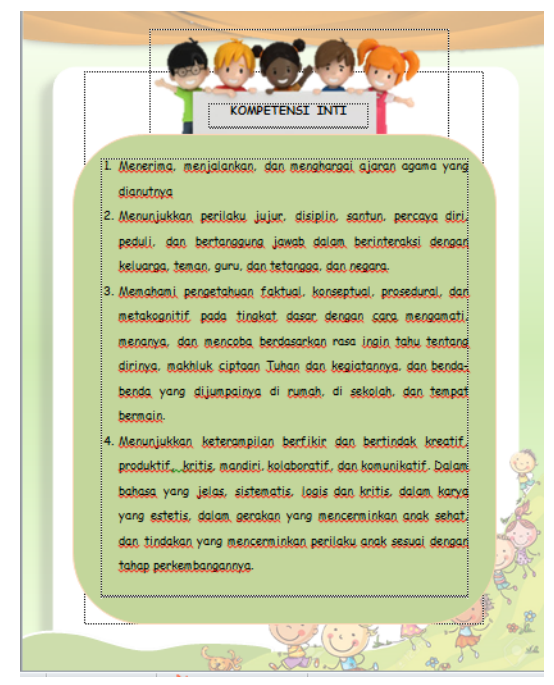

Figure 2. Competencies page

\subsection{Basic Competencies and Indicators.}

Basic competence is a competency that must be mastered by students in each subject. This indicator is obtained from basic competencies that can be developed into several indicators, then the indicator is reduced to a learning objective in accordance with Bloom's Taxonomy.

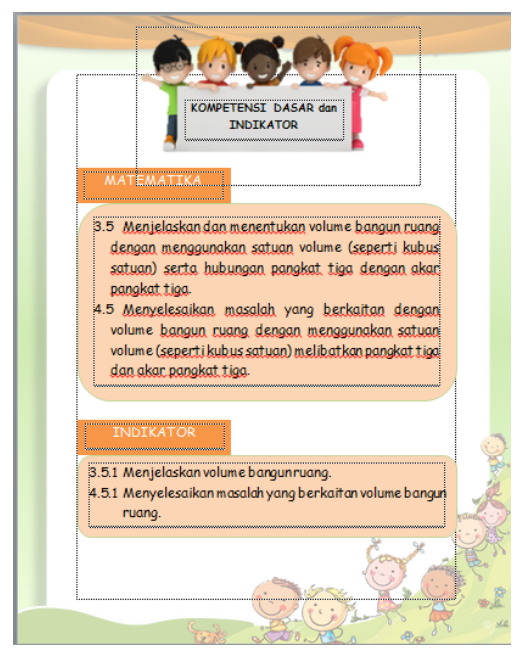

Figure 3. Basic Competence page

\subsection{Learning Objectives.}

It is a development of basic competencies that contain goals to be mastered or achieved by students in learning. 


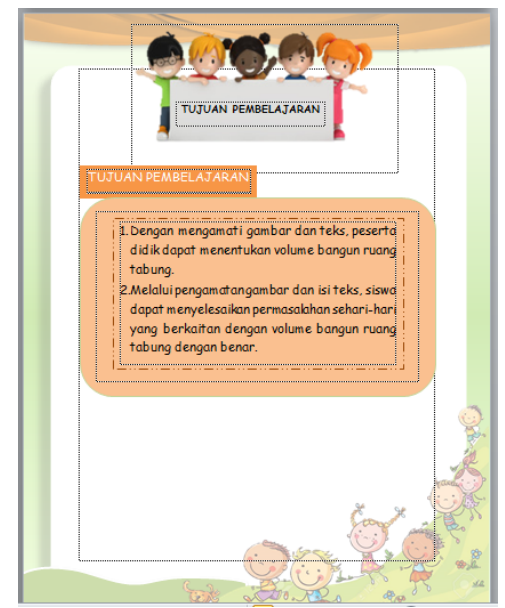

Figure 4. Indicator Pages and Learning Objectives

\subsection{Story}

The story presented relates to the culture in the local area, especially the jambi area.

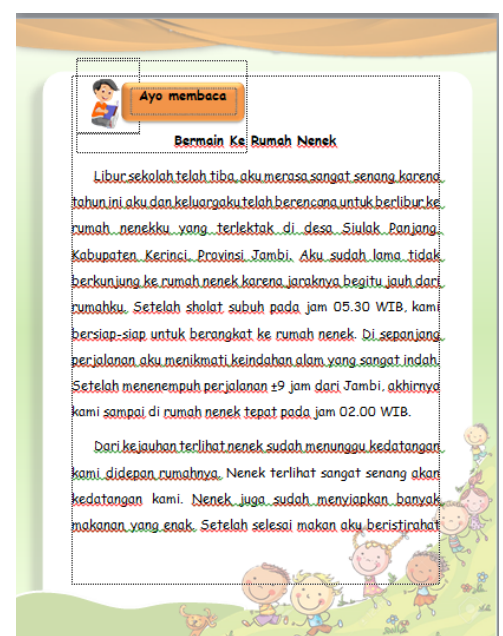

Figure 5. Story page

\subsection{Questions}

This page contains several questions about the story that has been presented.

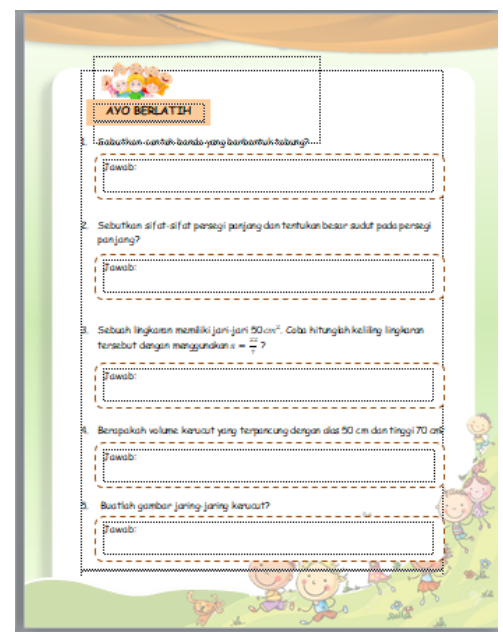

Figure 6. Questions page 


\subsection{Description of the material}

Description of the material contains explanations of material related to the story and in accordance with the basic competencies that students must master in the learning process.

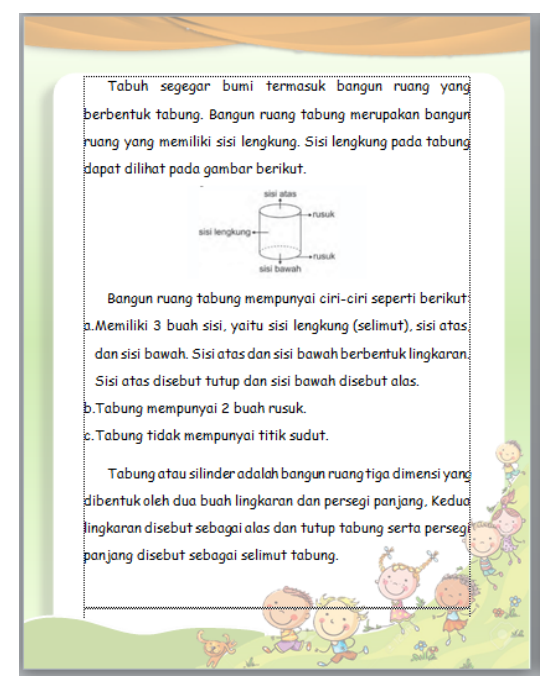

Figure 7. Material Description Page

\subsection{Evaluation}

Evaluations are given to measure students' abilities in the form of exercises and assignments related to the lessons that have been delivered.

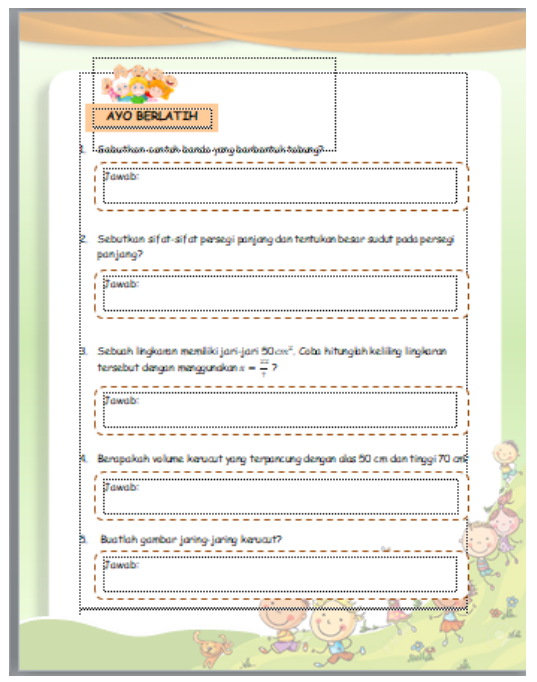

Figure 8. Evaluation Page

\subsection{Crafts}

Craft is a task given by the teacher to measure students' skills. Crafts are given after students learn all the material in one lesson. 


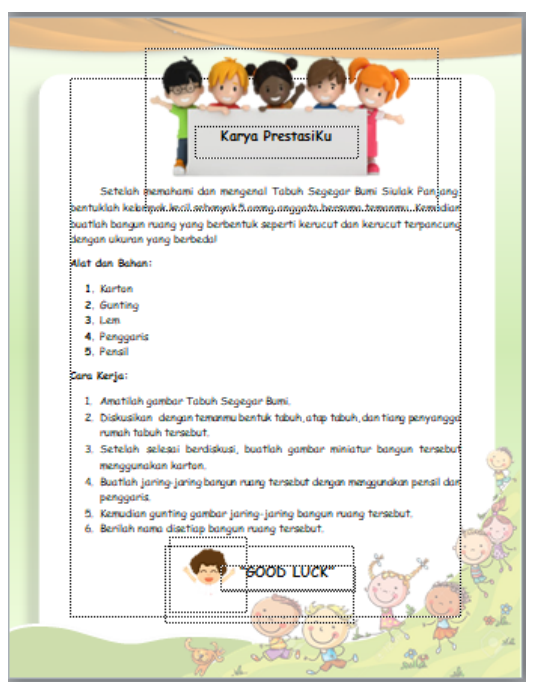

Figure 9. Craft Page

The implementation phase was tested on 5th grade elementary school students to determine students' perceptions, interests and motivations. After the module has been developed, the electronic module is tested on V grade students of SD Negeri 64/I Muara Bulian as teaching material in learning activities that last for $2 \times 45$ minutes. Before learning activities take place, $\mathrm{V}$ grade students are divided into 5 small groups with the number of students in each group of 5 students. After the trial run is completed, students are asked to fill in the response questionnaire, the questionnaire of motivation and the questionnaire of interest in using the 3D module ethnocontructivism-based electronic module Professional Pageflip in the learning process.

The results of perception data obtained from students using the perception questionnaire on the use of electronic modules in learning activities can be seen in the following table.

Table 2. Results of assessing students' perceptions of e-modules in learning

\begin{tabular}{|c|c|c|c|c|c|c|c|c|c|}
\hline \multicolumn{4}{|c|}{ Classification } & \multirow[b]{2}{*}{ Mean } & \multirow[b]{2}{*}{ Median } & \multirow[b]{2}{*}{ Mode } & \multirow[b]{2}{*}{ Min } & \multirow[b]{2}{*}{ Max } & \multirow{2}{*}{$\%$} \\
\hline Questionnaire & Interval & Category & Total & & & & & & \\
\hline \multirow[t]{5}{*}{ Perception } & $20.0-36.0$ & Very Not Good & 0 & & & & & & 0 \\
\hline & $36.1-52.0$ & Not Good & 0 & & & & & & 0 \\
\hline & $52.1-68.0$ & Enough & 28 & 61.97 & 61.00 & 61 & 57 & 81 & 93.4 \\
\hline & $68.1-84.0$ & Good & 2 & & & & & & 6.6 \\
\hline & $84.1-100.0$ & Very Good & 0 & & & & & & 0 \\
\hline Total & & & 30 & & & & & & 100 \\
\hline
\end{tabular}

Table 2 explained regarding the statistical description of students' perceptions on the use of e-module ethnocontructivism based on 3D Pageflip Professional it can be seen that the score scores obtained from 30 respondents produced valid data with an average of 61.97 , a median of 61.00 , mode 61 , minimum value of 57 and a value of a maximum of 81 .

To show the results of students' perceptions included in the excellent, good, enough, not good, and not very good categories, it can be seen in the table based on the interval of scores. Data obtained by 30 respondents showed that the perception results were included in the sufficient category with a frequency of 28 students and a percentage of $93.4 \%$. Judging from the data generated the perception questionnaire shows that there is a positive response from students in the sufficient category. 
Table 3. Results of assessment of student interest in e-modules in learning.

\begin{tabular}{|c|c|c|c|c|c|c|c|c|c|}
\hline \multicolumn{4}{|c|}{ Classification } & \multirow{2}{*}{ Mean } & \multirow{2}{*}{ Median } & \multirow{2}{*}{ Mode } & \multirow{2}{*}{ Min } & \multirow{2}{*}{ Max } & \multirow{2}{*}{$\%$} \\
\hline Questionnaire & Interval & Category & Total & & & & & & \\
\hline \multirow[t]{2}{*}{ Interest } & \begin{tabular}{|c|}
$20.0-36.0$ \\
$36.1-52.0$ \\
$52.1-68.0$ \\
$68.1-84.0$ \\
$84.1-100.0$ \\
\end{tabular} & $\begin{array}{l}\text { Very Not Good } \\
\text { Not Good } \\
\text { Enough } \\
\text { Good } \\
\text { Very Good } \\
\end{array}$ & $\begin{array}{c}0 \\
0 \\
3 \\
24 \\
3 \\
\end{array}$ & 75.90 & 76.50 & 81 & 62 & 88 & $\begin{array}{c}0 \\
0 \\
9.9 \\
80.1 \\
10 \\
\end{array}$ \\
\hline & Total & & 30 & & & & & & 100 \\
\hline
\end{tabular}

Table 3 explained regarding the statistical description of students' interest in using emodule ethnocontructivism based on 3D Pageflip Professional it can be seen that the score scores obtained from 30 respondents produced valid data with an average of 75.90 , median 76.50 , mode 81 , with a minimum value of 62 and the maximum score is 88 . Based on the interval score of students' interest in the use of 3D Pageflip Professional ethnocontructivism electronic modules consisting of 30 respondents included in both categories with a frequency of 24 students and a percentage of $80.1 \%$.

Table 4. Results of assessing students' motivation towards e-modules in learning. Classification

\begin{tabular}{cccccccccc}
\hline Questionnaire & Interval & Category & Total & Mean & Median & Mode & Min & Max & $\%$ \\
\hline \multirow{4}{*}{ Motivation } & $20.0-36.0$ & Very Not Good & 0 & & & & & & 0 \\
& $36.1-52.0$ & Not Good & 0 & & & & & \\
& $52.1-68.0$ & Enough & 0 & 76.93 & 77.00 & 74 & 69 & 90 & 0 \\
& $68.1-84.0$ & Good & 28 & & & & & & 93,4 \\
& $84.1-100.0$ & Very Good & 2 & & & & & 6,6 \\
\hline
\end{tabular}

Based on Table 4. Regarding the statistical description of Shiva's motivation on the use of the ethnoconstructivism electronic module based on 3D Pageflip Professional shows that for obtaining a score of 30 respondents produced valid data for Shiva's motivation with an average value of 76.93, a median of 77.00 , mode 74, with a minimum value of 69 and the maximum value is 90 . Based on the score interval, it can be obtained the results of student motivation from 30 respondents included in both categories with a frequency of 28 and a percentage of $93.4 \%$. The results of the motivation questionnaire data show that students' motivation in learning to use electronic modules is in the good category, meaning that the use of electronic modules can make students eager to learn so that student learning outcomes increase (Prime, 2017; Anggraini \& Perdana, 2019; Maison et al, 2019).

The last stage is the evaluation phase, this stage is carried out by conducting a feasibility test of 3D Pageflip Professional ethnocontructivism electronic module. Data obtained from the results of student activities during learning activities using ethnocontructivism electronic module based on 3D Pageflip Professional. Student activities are an inseparable part of the interactions that are triggered by learning media development results (Nurzaelani, Kasman, \& Achyanadia3, 2013). The results of perception data on the use of 3D Pageflip Professional ethnocontructivism-based electronic modules produced the same perception, motivation and interest using statistic descriptive. Perceptions of students included in the category enough, while the interests and motivation of students included in both categories. Can be seen from each questionnaire. Students 'perception of the average value of 61.97 , a median of 61.00 , mode 61 , with a minimum value of 57 and a maximum value of 81 . Based on the interval score can be obtained students' perceptions of 30 respondents included in the category enough with a 28 students of $93.4 \%$.

For the results of the interest questionnaire obtained an average value of 75.90 , a median of 76.50 , mode 81 , with a minimum score of 62 and a maximum value of 88 . Based on the interval score of students' interest in the use of a 3D Pageflip Professional 
ethnocontructivism-based electronic module consisting of 30 respondents included in both categories with a frequency of 24 students and a percentage of $80.1 \%$. From the data generated shows students' interest in learning to use electronic modules well, meaning electronic modules can make students have a desire to learn, so students are always happy to learn. The results of the motivation questionnaire obtained an average value of 76.93 , a median of 77.00, mode 74, with a minimum value of 69 and a maximum value of 90 . Based on the interval score, student motivation results from 30 respondents included in both categories with a frequency of 28 and a percentage of $93,4 \%$ The results of the motivation questionnaire data indicate that student motivation in learning to use electronic modules is classified in either category, meaning that the use of electronic modules can make students eager to learn so that student learning outcomes increase (Prime, Susbiyanto \& Anggraini, 2019; Anggraini \& Perdana, 2019). Based on the results of these data can be interpreted that the perceptions, interests and responses of elementary school students are included in both categories, so that the electronic module is feasible to learning process.

\section{Conclusion and Sugesstion}

This research produces teaching materials in the form of a 3D Pageflip Professional ethnocontructivism-based electronic module developed adapted Branch, 2009 and has an attraction for students. Judging from the questionnaire responses, interests, and motivation of students towards the ethnocontructivism electronic module using the 3D Pageflip application, scores were obtained with good criteria. For perception based on interval scores on the 28 students of $93.4 \%$. For interests with a 24 students of $80.1 \%$. Furthermore, the results of student motivation with a 28 students' of $93.4 \%$. The results of the study can be said that the use of ethnocontructivism electronic modules in the learning process is included in both categories, so the developed electronic modules are considered suitable for use in elementary $\mathrm{V}$ grade learning.

\section{Acknowladgment}

The researcher would like to express his gratitude to the Minister of Research and Technology for the research grant with the number 060/SP2H/RT/DRPM /2019 and the researcher would like to thank the principal and teachers of SD / 64 State Muara Bulian.

\section{References}

Abdel Rahman Ibrahim, M. H. (2016). Classroom Management The Effectiveness of Teacher's Roles. Education and Linguistics Research, 2(1), 69. https://doi.org/10.5296/elr.v2i1.9053

Alqomayi, S. (2018). Kearifan Lokal Berbasis Islam Dalam Pelestarian Lingkungan Hidup. IBDA : Jurnal Kajian Islam Dan Budaya, 10(1), 15-29. https://doi.org/10.24090/ibda.v10i1.46

Anggraini, L., \& Perdana, R. (2019). Hubungan Sikap dan Percaya Diri Siswa Pada Mata Pelajaran IPA di Sekolah Menengah Pertama. SPEKTRA: jurnal Kajian Pendidikan Sains, 5(2), 188-199.

Anggraini, L., \& Perdana, R. (2019). Deskripsi Sikap Siswa Pada Mata Pelajaran Fisika di Sekolah Menengah Pertama. PSEJ (Pancasakti Science Education Journal), 4(2), 8396.

Asrial, \& Dwijaya, A. (2014). Pengaruh Penggunaan Model Pembelajaran Group Investigasi Dan Motivasi Belajar Siswa Terhadap Pemahaman Konsep Sistim Koloid. J. Ind. Soc. Integ. Chem, 6(2), 1-6.

Asrial, Syahrial, Kurniawan, D. A., Chan, F., Nugroho, P., Pratama, R. A., \& Septiasari, R. (2019). Identification: The Effect Of Mathematical Competence On Pedagogic Competency Of Prospective Teacher. Humanities \& Social Sciences Reviews, 7(4), 85-92.

Asrial, Syahrial, Kurniawan, D. A., Perdana, R., \& Nugroho, P. (2019). Supporting Technology 4 . 0 : Ethoconstructivist Multimedia for Elementary Schools. IJOE, 15(14), 54-66. 
Asrial., Syahrial., Kurniawan, D. A., Chan, F., Septianingsih, R., Perdana, R. (2019). Multimedia Innovation 4.0 in Education: E-Modul Ethnoconstrucivism. Universal Journal of Educational Research. 7(10), 2098-2107.

Astalini, Kurniawan, D. A., \& Sumaryanti. (2018). Sikap Siswa Terhadap Pelajaran Fisika di SMAN Kabupaten Batanghari. Jurnal IImu Pendidikan Fisika, 3(2), 59-64.

Astalini., Kurniawan, D. A., Kurniawan, N., Anggraini, L. (2019). Evaluation of Student's Attitude Toward Science in Indonesia. Open Journa of Educational Research (OJER), 3(1), 1-12.

Astalini, Kurniawan, D. A., Darmaji, Sholihah, L. R., Perdana, R. (2019).Characteristics Of Students' Attitude To Physics In Muaro Jambi High School. Humanities \& Social Science Reviews (HSSR), 7(2), 91-99

Branch. (2009). "Instructional Design: The ADDIE Approach". London: Library of Congress.

Budiarti, R. S., Harlis., Natalia, D. (2020). High Oder Thinking Skills for Biology Education: Applied Microbiology Learning Videos Based on Jambi Local Wisdom. Universal Journal of Education Resaerch, 8(2), 689-694.

Cahyanti, F. D., Sinaga, P., \& Amsor, N. A. (2018). Effectiveness of the new generation ebook application for mobile phones in improving the conceptual mastery of kinematics. International Journal of Mobile Learning and Organisation, 13(2), 217. https://doi.org/10.1504/ijmlo.2019.10017848

Citrawathi, D. M., Adnyana, P. B., \& Santiasa, M. P. A. (2016). Analisis Kebutuhan Untuk Pengembangan Modul Inkuiri Berbasis Pertanyaan (Mibp) Di Smp. JPI (Jurnal Pendidikan Indonesia), 5(1), 1-11. https://doi.org/10.23887/jpi-undiksha.v5i1.8289

Darmaji., Astalini., Kurniawan, D. A., Parasdila, H., Irdianti., Susbiyanto., Ikhlas, M., Kuswanto. (2019). E-Module Based Problem Solving in Basic Physics Practicum for Science Process Skills. International Journal of Online and Biomedical Engineering (IJOE), 15 (15). 4-17

Darmaji., Astalini., Kurniawan, D. A., Parasdila, H., Irdianti., Hadijah, S., Perdana, R. (2019). Practicum Guide: Basic Physics Based of Science Process Skills. Humanities and Social Science Reviews, 7(4), 151-160

Djidu, H., \& Jailani, J. (2018). Developing problem based calculus learning model. Jurnal Kependidikan: Penelitian Inovasi Pembelajaran, 2(1), 68. https://doi.org/10.21831/jk.v2i1.12689

Imansari, N., \& Sunaryantiningsih, I. (2016). Volt jurnal ilmiah pendidikan teknik elektro. VOLT: Jurnal IImiah Pendidikan Teknik Elektro, 2(1), 11-16. Retrieved from http://jurnal.untirta.ac.id/index.php/VOLT/article/view/1478/1169

Kurniawan, D.A., Astalini., Anggraini, L. (2019). Evaluasi Sikap Siswa Smp Terhadap Ipa Di Kabupaten Muaro Jambi. Jurnal IImiah Didaktika: Media Ilmiah Pendidikan dan Pengajaran, 19(1), 124-139.

Koderi. (2017). Pengembangan Modul Elektronik Berbasis SAVI Untuk Pembelajaran Bahasa Arab. Teknologi Pendidikan, 19(3), 206-223. https://doi.org/https://doi.org/10.21009/JTP1903.4

Manasia, L. (2015). Enjoyment of Learning in Upper Secondary Education. An Exploratory Research. Procedia - Social and Behavioral Sciences, 180(December), 639-646. https://doi.org/10.1016/j.sbspro.2015.02.172

Maison., Ernawati, M. D. W., Budiarti, R. S., Kurniawan, W., Ningsih, Y., Puspitasari, T. O., Jannah, N., Putra, D. S. (2019). Learning in Nature Science: Social Implication, Normality of Scientist., Attitudes Towards Investigation of Natural Science, and Interest Adds To Science Learning Time. International Journal of Scientific \& Technology Research, 8(12), 1478-1484.

Maison., Astalini., Kurniawan, D. A., Perdana, R., Anggraini, L. (2019). The Phenomenon of Physicology Senior High School Education: Relationship of Students' Attitudes towards Physics, Learning Style, Motivation. Universal Journal of Educational Research. 7(10), 2199-2207.

Maison., Darmaji., Astalini., Kurniawan, D. A., Sumaryanti., Perdana, R. (2020). Supporting Assessment in Education: E-Assessment Interest in Physics. Universal Journal of 
Education Research, 8(1) 89-97.

Nurzaelani, M. M., Kasman, R., \& Achyanadia3, S. (2013). Pengembangan Bahan Ajar Integrasi Nasional Berbasis Mobile. Indonesian Journal of Conservation, 2(1), 33-44. https://doi.org/10.1080/15398285.2016.1201787

Perdana, F. A., Sarwanto, S., Sukarmin, S., \& Sujadi, I. (2017). Development of e-module combining science process skills and dynamics motion material to increasing critical thinking skills and improve student learning motivation senior high school. International Journal of Science and Applied Science: Conference Series, 1(1), 45. https://doi.org/10.20961/ijsascs.v1i1.5112

Perdana, R., Subiyantoro, C., \& Anggraini, L. (2019). Sikap dan Motivasi pada Mata Pelajaran Fisika. SPEKTRA: Jurnal Kajian Pendidikan Sains, 5(2), 178-187.

Sari, I. P. (2018). Implementasi Model Addie Dan Kompetensi Kewirausahaan Dosen Terhadap Motivasi Wirausaha Mahasiswa. Jurnal Ekonomi Pendidikan Dan Kewirausahaan, 6(1), 83. https://doi.org/10.26740/jepk.v6n1.p83-94

Sari, W., Jufrida, \& Pathoni, H. (2017). Pengembangan Modul Elektronik Berbasis 3D Pageflip Professional pada Materi Konsep Dasar Fisika Inti dan Struktur Inti Mata Kuliah Fisika Atom dan Inti. Jurnal EduFisika, 02(01), 38-50.

Silalahi, P. (2015). Pengembangan Model Pelatihan Pengintegrasian Teknologi Informasi dan Komunikasi dalam Pembelajaran Matematika bagi Guru SD. Jurnal Teknologi Pendidikan Vol., 17(1), 1-14.

Sukasni, A., \& Efendy, H. (2017). The Problematic of Education System in Indonesia and Reform Agenda. International Journal of Education, 9(3), 183. https://doi.org/10.5296/ije.v9i3.11705

Suyatna, A., Maulina, H., Rakhmawati, I., \& Khasanah, R. A. N. (2018). Electronic Versus Printed Book: Comparison Study on the Effectivity of Senior High School Physics Book. Jurnal Pendidikan IPA Indonesia, 7(4), 391-398. https://doi.org/10.15294/jpii.v7i4.14437

Syahrial, Asrial, Kurniawan, D. A., \& Piyana, S. O. (2019). Jurnal Teknologi Pendidikan EModul Etnokontruktivisme: Implementasi Pada Kelas V Sekolah Dasar. Junrnal Teknologi Pendidikan, 21(1), 165-177.

Tegeh, I. M., \& Kirna, I. M. (2013). Pengembangan Bahan Ajar Metode Penelitian Pendidikan Dengan Addie Model. Jurnal Ika, 1(1), 12-26.

Trisiana, A., \& Wartoyo. (2016). Desain Pengembangan Model Pembelajaran Pendidikan Kewarganegaraan Melalui Addie Model Untuk Meningkatkan Karakter Mahasiswa Di Universitas Slamet Riyadi Surakarta. PKn Progresif, 11(1).

Wijana, N. (2015). Berorientasi Kearifan Lokal Ke Dalam Materi Ajar Soft Skill Mahasiswa Jurusan Pendidikan Biologi Universitas Pendidikan Ganesha. Jurnal Pendidikan Indonesia, 4(2), 647-657.

Wulansari, E. W., Kantun, S., \& Suharso, P. (2018). Pengembangan E-Modul Pembelajaran Ekonomi Materi Pasar Modal Untuk Siswa Kelas Xi Ips Man 1 Jember Tahun Ajaran 2016/2017. Jurnal Pendidikan Ekonomi: Jurnal IImiah IImu Pendidikan, IImu Ekonomi Dan IImu Sosial, 12(1), 1. https://doi.org/10.19184/jpe.v12i1.6463 